\title{
Agitated Boundaries: Non-Human Creatures and Supernaturalism in Colin Cotterill's Siri Paiboun Crime Series
}

\author{
PANIDA BOONTHAVEVEJ \\ Department of Western Languages, \\ Faculty of Archaeology \\ Silpakorn University, Thailand \\ boonthavevejp@gmail.com
}

\begin{abstract}
This article is a study of animals and supernaturalism in the Siri Paiboun crime series, featuring Siri Paiboun, the national coroner of the newly established Lao People's Democratic Republic. Mainly informed by critical theories of animal studies, the article contends that the animal offers a critical intervention of crime fiction studies. Animals in the series are not just tools or companions to humans, but active agents that, along with preternatural happenings, operate to collapse the distinction between human and non-human animals. Categorised into speaking and gazing animals, fantastic animals, and real and symbolic animals, these animals serve to blur the demarcation line between subjects and objects, physical and spiritual forms, and animals and colonised subjects, respectively. Eventually, the trans-species traffic, witnessed by some of the human characters, results in the decentring of the anthropomorphic definition of crime. Under supernatural circumstances, animals in this crime series function as a constant reminder that they can suffer like humans, and crime against animals should thus be punishable by law as crime against humans.
\end{abstract}

Keywords: crime fiction; animal studies; supernaturalism; Colin Cotterill; Siri Paiboun

\section{INTRODUCTION}

In Anarchy and Old Dogs (Cotterill, 2007), a crime novel set in 1977, a fatherless boy named Sing was found missing in Pakse, a city in southern Laos. Days later, his body was washed up on the bank of the Mekhong river a hundred miles from his home. Upon the request of Sing's mother, Siri Paiboun and Civilai Songsawat, members of the politburo who happened to be visiting the city, took a ferry to where the body was discovered, trapped in a local fisherman's net. There, on the riverbank, appeared a $p a k h a$, the Lao name for the local river dolphins that feature prominently in local folktales.

The gray-green sheen of some large creature had become visible just above the surface of the river at the far bank and was moving now directly to where the old men sat. The dolphin's head emerged not far from their feet. Its mouth was curved into a smile. It looked up and blew a spout of water from its long pointed snout that hit Civilai square in the chest. The politburo man looked with amazement, first at the animal, then at Siri, and burst into laughter. Siri joined in. The pa kha, sensing a receptive audience, belly flopped back and forth in front of them. Siri put his arm around his friend's shoulder and enjoyed the show. (Cotterill, 2007, p. 156)

Siri then decided to join the dolphin in the river, and ride on the creature's back. Uncannily, it later dawned on him that the boy's spirit had come to rest in the pa kha, a site where the physical form of a non-human merged with the spiritual form of a human.

The aforementioned phenomenon is one among several that have given rise to a curious question concerning the special roles of non-human creatures and supernaturalism in the Siri Paiboun crime series (2004-2019), written by the British writer Colin Cotterill (b. 1952). The article thus aims to address the question by investigating the nature and roles of the connection between animals and supernaturalism in the Siri Paiboun series, as well as its repercussions. 
Anchored in critical animal studies, the article relies on textual analysis of the fourteen crime novels. It starts with a brief survey of critical studies of animals in literature, and narrows down towards studies of animals in crime fiction. Afterwards, the article becomes more focused on the intersection of animals and supernaturalism within the context of Cotterill's crime series, discussing the characteristics and consequences of the trans-species border crossing experienced by its major characters. Eventually, I propose that the co-presence of animals and supernaturalism in the Siri Paiboun crime series contributes to the dismantling of the boundary between human and non-human animals. Furthermore, the interspecies transgression inevitably brings about the de-centring of the anthropomorphic definition of crime. Therefore, animals in this crime series function as a constant reminder that they can also suffer like humans, and that violence against them should be treated on the same plane as violence against humans.

\section{ANIMALS IN LITERARY STUDIES}

Studies of animals in socio-historical contexts possibly emerged as early as the late twentieth century. In Regarding Animals, Arluke and Sanders (1996) suggest that the meanings of animals are socially defined. As social constructions, these meanings are "cultural phenomena - part of the normative order of the society in which they occur" (Arluke \& Sanders, 1996, p. 10). It set the precedent for later studies about animals, such as Animal Spaces, Beastly Places: New Geographies of Human-Animal Relations, in which Philo and Wilbert (2000) explore animals in various geographical, social, and historical contexts. They not only focus on animals in their local material spaces, e.g. settlements, fields, farms, and factories, but also animals in the spoken and written spaces, e.g. folklore, nursery rhymes, novels, and treatises, as well as in the virtual spaces, e.g. television, cinema, cartoons, and animation (Philo \& Wilbert, 2000, p. 5).

However, when we look at how humans regard animals in modern Western societies, one of the most glaring consistencies is inconsistency (Arluke \& Sanders, 1996, p. 4). This can be illustrated in Looking at Animals in Human History, in which Kalof (2007) studies the perceptions of animals throughout history, from the Middle Ages to the twentieth century. Remarkably, from René Descartes (1596-1650) to Jacques Lacan (1901-1981), humans have always been thought of "as the conjunction of a living, animal body and a divine soul, the latter often identified with logos, or, more simply, with the uniquely human capacity for language itself" (Cole, 2011, pp. 2-3). Cohen (2003) points out in "Animals in Medieval Perceptions: The Image of the Ubiquitous Other" that it was the breach of the barrier between human and animal that endowed both sides with demonic qualities. For example, the fact that werewolves were "more frightening than any animal precisely because they underwent a metamorphosis from human to animal and back, embodied this belief" (Cohen, 2003, p. 65).

Later, in the noughties, with the advent of critical animal studies, the species boundary, which had been consistently patrolled, started to be rigorously challenged because an increasing range of animals have been drawn into closer emotional association with modern cultures (Franklin, 1999, p. 3). Calarco (2008) explains in Zoographies: The Question of the Animal from Heidegger to Derrida that animal studies, sometimes called "human-animal studies," comprises a wide range of disciplines within the humanities, social sciences, and biological and cognitive sciences (p. 2). In the meantime, in "From Animal to Animality Studies," Lundblad (2009) differentiates between animal studies and animality studies. To him, both share an interest in how we think about "real" animals, but while animal studies can be seen as work that explores representations of animality and related discourses with an emphasis on advocacy for non-human animals, animality studies becomes work that emphasises the 
history of animality in relation to human cultural studies, without an explicit call for non-human advocacy (Lundblad, 2009, p. 500).

Although animality has been a hotbed of philosophical debates for centuries, animals were, until recently, underrepresented in literary studies. In "Literary Animal Agents," McHugh (2009) posits that animals emerged as significant figures in English literature only in terms of metaphors. From earlier Enlightenment views, animals teach people how to become human as literary animals are regarded as substitutes for human subjects in the making. Nonetheless, the aesthetic structures of metaphor seem unable to bear animal agency (McHugh, 2009, p. 488). Conversely, in animal studies, animals are being reconceptualised as active participants in all sorts of cultural production, and as agents of an order different from that of human subjectivity. Yet, animal agency can never simply oppose human identity, and animal agents are never separable from human presences (McHugh, 2009, pp. 490-491). Hence, an investigation into new and old means of representing animals in literature "can contribute to a broader understanding of porous species forms and can help model knowledges and responsibilities attendant to life in the twenty-first century" (McHugh, 2009, pp. 491-492).

Arguably, the application of critical animal studies to literary studies has been developed into three major tracks, namely, animals and modernism; animals and postmodernism/postcolonialism; the redefinition of human-animal relations (Ohrem and Calarco, 2018). First, the modernist approach to animal studies takes into account the species boundary that has remained intact. For example, in What Animals Mean in the Fiction of Modernity, Armstrong (2008) locates "tracks" left by animals in canonical texts, or, "the ways cultural formations are affected by the materiality of animals and their relationships with humans" (Armstrong, 2008, p. 3). Afterwards, in Stalking the Subject: Modernism and the Animal, Carrie Rohman (2009) attempts to recast the modernist subject with reference to animality, and also to situate several ideological discourses within the period in relation to the problematic nature of the interspecies boundary (p. 12). By bringing to bear recent theories of animality upon literary modernism, her study reveals animality as a fundamental locus of identity construction since "the specter of the animal profoundly threatens the sovereignty of the Western subject of consciousness in modernist literature" (Rohman, 2009, p. 11). In other words, the sovereignty of the human subject hinges upon the differentiation between the human and the animal, and upon "the material reinstantiation of that exclusion through various practices such as meat-eating, hunting, and medical experimentation" (Rohman, 2009, p. 16).

The second track of critical animal studies in relation to literary studies features the species boundary being rigorously challenged. In Animals in Film, Burt (2004) claims that "the animal is caught in an uncertain space between the natural and the contrived" (p. 10). On the one hand, an emotional response to animals is a natural expression of sentiment toward nonhuman creatures. On the other hand, it can be said that it is film itself that has increasingly influenced the constructions of the animal in the public domain (Burt, 2004, p. 10). In Literature and Animal Studies, Mario Ortiz Robles (2016) argues that the constant presence of animals in literature suggests that literature is that discourse "whereby humans simultaneously declare their difference from animals, and take the measure of their suggestive similarities" ( $p$. 2). Animals, as we know them, are therefore, a literary invention.

Furthermore, while postcolonial critiques work to illuminate the dialectic between Western subjectivity and the non-Western "other" (Rohman, 2009, p. 12), the prioritisation of humans and human interests over those of other species on earth in effect generates and repeats the racist ideologies of imperialism on a planetary scale (Huggan \& Tiffin, 2010, p. 6). In other words, colonised subjects are discriminated and relegated to the "other" in a colonial system whereas the interests of non-human animals are sidelined by those of human animals. The hierarchisation of different life forms has been complicit in colonialist and racist exploitation from the time of imperial conquest to the present day (Huggan \& Tiffin, 2010, p. 6) 
Lastly, the third track of critical animal studies and literature seeks to redefine humananimal relations. In "Introduction: Literature Beyond the Human," Herman (2016) uses the term "creature" to establish non-hierarchical understandings of non-human personhood, and to refer to the mutually shaping relationship between humans and non-humans (p. 11). Afterwards, in Imperfect Creatures: Vermin, Literature, and the Sciences of Life, 1600-1740, instead of placing these creatures at the lowest rungs of the Great Chain of Being, Lucinda Cole (2019) offers "a heterarchical reading of key texts in early modern literature in order to explore how sociohistorical, biopolitical, and ecological conditions reconfigure seventeenth-century perceptions of fleas, curs, rats, worms, and other vermin" (p. 9). For example, the relationship among vermin, plague, and witches in William Shakespeare's Macbeth reveals "the associations between natural and spiritual contagion, between environmental pollution and moral/political corruption, which are mutually constitutive" (Cole, 2019, p. 36). Hence, the cold, foggy, and rainy climate of Macbeth's Scotland "evokes an association between the filthy air with the swarming evils that plague the kingdom" (Cole, 2019, p. 37).

\section{ANIMALS IN CRIME FICTION}

One literary genre in which the presence of animals has been persistent, albeit marginalised, is crime fiction. While the species boundary is still clearly marked, the roles of animals in crime fiction can be categorised into three major groups: animals as tools of crime; animals as companions to humans; animals as non-human agents.

One example of animals as tools of crime is found in The Hound of the Baskervilles (1902) by Sir Arthur Conan Doyle (1859-1930). On the one hand, the story of the ghastly hound circulates as the local legend surrounding the Baskerville estate. On the other, the real animal actually exists. It is a mixed breed between a bloodhound and a mastiff. Raised by Stapleton, the hound was hidden in the old mine. Phosphorous was applied to make the hound glow to correspond with the myth (Doyle, 1994, p. 232). It was then released to attack Sir Charles and later Sir Henry, the rightful heirs to the estate.

Another example of animals as tools of crime resides in Bangkok 8 (2003), a novel by the British writer John Burdett (2003). In the novel, a swarm of venomous snakes were placed in a wooden crate in a grey Mercedes. Put under the influence of methamphetamine, the deadly creatures attacked and killed the driver and a police officer of the Royal Thai Police. Remarkably, animals as tools of crime are treated as objects or beasts, lacking linguistic ability and mental faculty.

Conversely, the second category of animals in crime fiction are given the status of companions, to remind man of his own humanity. For instance, in The Yellow Dog (1931) by the Belgian writer Georges Simenon (1903-1989), a yellow dog was seen wandering around the town of Concarneau in north-western France. It had been kept by Léon LeGlérec, a fisherman, the lover of Emma, who had been working as a waitress at the Admiral café. During the Prohibition, he was drawn into a bootlegging scam across the Atlantic. Later doublecrossed, he ended up in Sing Sing prison. During his time in jail, LeGlérec reflected:

The only company I had was a dog. I raised him on board, and he'd saved me from drowning once. In spite of all their rules over there, they let him stay in the prison - they have different ideas from us about that kind of thing [...]. (Simenon, 2013, p. 121)

After he returned to Concarneau seeking revenge, he lived with the dog on an abandoned boat, and later in the old watchtower at Cabélou Point (Simenon, 2013, p. 122).

In the third category, animals in crime fiction become agents, taking active roles in the murder of humans. For instance, in The Murders in the Rue Morgue (1841) by Edgar Allan Poe 
(1809-1849), Auguste Dupin investigates the horrible murders of Madame L'Espanaye and her daughter, Mademoiselle Camille. Mademoiselle Camille was apparently choked to death, and then her body was thrust up into the chimney. Meanwhile, the body of Madame L'Espanaye was found in a courtyard in the rear of the building. She was badly beaten, with her throat severely cut. It turned out they were killed by an Ourang-Outang belonging to a sailor. The animal grasped a razor, escaped from its closet one night, and disappeared from his apartment. Noticeably, the Ourang-Outang imitates human behaviour, in this case, the sailor's daily routine of shaving (Poe, 2008). Similarly, the imitation of humans is found in The Woman Who Wouldn't Die (Cotterill, 2013), in which Ugly, the protagonist's adopted dog, pretended to be drunk like his master in an effort to approach a group of Vietnamese engineers, and to figure out the real motive behind their arrival in Sanyaburi.

\section{ANIMALS AND SUPERNATURALISM IN THE SIRI PAIBOUN CRIME SERIES}

In addition to the three roles played by animals in crime fiction, it may be argued, animals can provoke in humans a sense of the uncanny. They also remind us of the porous boundaries between humans, animals, and things, often celebrated by indigenous peoples (Carstens, 2017, p. 94). In "Border Crossings: Animals, Tricksters and Shape-Shifters in Modern Native American Fiction," Payne (2017) suggests that modern Native American novelists use the presence of non-human tricksters to transgress boundaries: "between animals and humans, between Native and non-Native cultures, and between the earthly world and the fantastic" (pp. 186-187). In the context of Western societies, these tricksters challenge these binary constructions. In other words, they are agitators of the species boundary (Carstens, 2017, p. 95). Characteristically, non-human animals in these texts are "politicised, as well as liminal, inhabiting dreams and visions, straddling ahistorical, mythical time and the linear time of modernity" (Woodward, 2017, pp. 232-233).

One prominent case of the co-presence of animals and the uncanny in crime fiction is located in the Siri Paiboun series, which spans over the years 1976-1980, and features Siri Paiboun, a field surgeon in his seventies, who had been medically trained in France. As a party cadre, he fought in the Pathet Lao communist movement for over thirty years. In 1976, after his retirement, he was appointed the national coroner of the newly established Lao PDR. Stationed at the morgue of Mahosot hospital, he was usually accompanied by Geung Wattajak, one of the morgue assistants. As a result of their uncanny abilities, both of them experienced preternatural incidents that often involved non-human creatures. Those circumstances in effect turn these major characters into human tricksters inhabiting liminal space and time, between the normal and abnormal, the human and non-human, the living and dead.

In The Coroner's Lunch (Cotterill, 2004), Siri's physical description initially denormalises him. His peculiar eyes were "the bright green of well-lighted snooker-table felt, and they never failed to amuse him when they stared back from his mirror. He didn't know much about his real parents, but there had been no rumours of aliens in his blood" (Cotterill, 2004, p. 5). Later, he discovered that he was able to communicate with the spirits of the dead because he was the re-embodiment of Yeh Ming, a powerful Hmong shaman who had lived over a thousand years ago. Since the discovery, Siri had become aware of the amazing powers that lurked somewhere deep inside him (Cotterill, 2005, pp. 33-34). Initially, he fell into a fit of denial. However, after several preternatural encounters, he was resigned to his unusual ability. Meanwhile, Geung, the morgue assistant, is dehumanised. He was called a moron or a retard by Judge Haeng, from the Ministry of Justice, because of his Down Syndrome symptoms (Cotterill, 2004, pp. 32; 83). Properly trained by the previous coroner, Dr. Pongruk, however, 


\begin{abstract}
Geung had been the cornerstone of the morgue in its heyday. He'd carried corpses with respect, he'd cut them open and sewn them back together. He'd weighed the internal organs and put all the fluids in plastic bags - all the time talking to the spirits who'd stuck around to make sure their old bodies were being well taken care of. Siri often wondered whether this paranormal chitchat might be his fault in some way. Had he tuned the young man in to the wavelength or had Geung always carried the gift? One thing for certain was that as their relationship progressed, Mr. Geung's awareness of that other dimension strengthened. Those outside the loop assumed the lab assistant was talking to himself, perhaps an offshoot of his condition. [...] Like Dr. Siri, Mr. Geung usually preferred to keep the secret to himself. (Cotterill, 2018, pp. 27-28)
\end{abstract}

Arguably, the trans-species traffic Siri and Geung experienced under preternatural circumstances turns them into "agitators of boundaries" (Carstens, 2017, p. 95), intermediaries between the dead and the alive as well as human and non-human animals. This article, hence, examines the boundaries between human and non-human creatures that have been agitated in supernatural happenings in the Siri Paiboun crime series. Mainly, but not exclusively, informed by critical theories of animal studies, it purposefully demonstrates that animals in crime fiction, though still understudied, offer a critical, particularly non-anthropocentric, intervention of crime fiction studies, whereby both human and non-human animals find themselves as crime victims.

Animals encountered during Siri's criminal investigations may be classified, according to Robles (2016), into their modes of representation: talking animals; fantastic animals; symbolic animals; real animals. Talking animals are represented as though they are human, standing in for human attributes. Fantastic animals would include mythical animals like unicorns, dragons, and phoenixes, as well as human-animal hybrids such as mermaids, centaurs, and werewolves. Symbolic animals do not appear in literature in any concrete form, yet function as symbolic repositories for human ideals and anxieties. For example, warriors, evildoers, and racial others are often referred to as animals. Lastly, there are real animals, such as the horses, dogs, cats, apes, and birds that are often found in literature (Robles, 2016, pp. 22-23). Nevertheless, animals in the series are not just tools or companions but agents/actants inhabiting liminal space and time. Here, my contention is that the use of supernaturalism (in the forms of ghosts, possessions, trances, etc.), and animals in the Siri Paiboun crime series contributes to the collapse of the distinction between human and non-human animals. Therefore, in the co-presence of animals and supernaturalism, Siri and Geung witnessed the de-regimentation of the boundary between subjects and objects, the physical and the spiritual, and the real and the representational.

\title{
SPEAKING AND GAZING ANIMALS: BETWEEN SUBJECTS AND OBJECTS
}

First, the border between subjects and objects is destabilised as Siri and Geung discover the agency of non-human animals while carrying out their investigative tasks. In the Siri Paiboun series, hierarchised relationships between species, which are considered the hallmark of the Enlightenment, are replaced by non-hierarchised ones.

In A Discourse on the Method of Correctly Conducting One's Reason and Seeking Truth in the Sciences, Descartes (b. 1637) lays down the differences between humans and animals, by endowing humans with the rational soul, the faculty of imagination, and linguistic ability. Meanwhile, animals are compared to machines with no, or limited, language and mental powers. They are unable to use words or other signs to volubly express their thoughts as humans do. They behave according to the nature allowed by their organs, nerves, and muscles (Descartes, 2006, pp. 46-48). Heidegger (b. 1983) would later address the question concerning the essence of animality and thus the essence of life in The Fundamental Concepts of Metaphysics: World, Finitude, Solitude (Heidegger, 1995, p. 207). Heidegger suggests that the animal does not act, it simply behaves, since it has no agency. Conversely, men have "access to beings," or an awareness of their being and other beings, and thus can "speak meaningfully 
of the world and world-formation of man" (Heidegger, 1995, p. 284). Having taken the above postulations into account, I would then propose that animals in the Siri Paiboun series are not placed on the lower rung of creatures, but perform active parts in the stories, engaging the human characters and propelling their courses of action. This is because while one can address the spirits of dead animals, they can in turn be addressed by them. An animal has a face that is capable of initiating a glance and a speech. For Jacques Derrida, in Writing and Difference (1978), non-human animals should not be relegated to the lower status of objects since they look at and talk to human animals.

\begin{abstract}
[T]he face is the inaugural unity of a naked glance and of a right to speech. But eyes and mouth make a face only if, beyond need, they can "let be," if they see and they say what is such as it is, if they reach the Being of what is. But since Being is, it cannot simply be produced, but precisely must be respected by a glance and a speech; Being must provoke them, interpellate them. There is no speech without the thought and statement of Being. (Derrida, 1978, p. 143)
\end{abstract}

The uncanny circumstances that Siri encountered usually involve non-human animals that can address or gaze at him. For instance, the dog named Saloop was wandering near his old apartment overlooking Hay Sok temple, and moved to the new housing unit near That Luang. One may claim that:

\begin{abstract}
Saloop had been Siri's dog. Or perhaps it would be fairer to say that Siri had been Saloop's man. The dog had adopted Siri, saved his life once, and become a fixture in the yard of the bungalow at That Luang. Then one day he' $d$ been murdered by the neighbor in cold blood - brained with a garden shovel. (Cotterill, 2009, p. 14)
\end{abstract}

In The Merry Misogynist (Cotterill, 2009), Siri had several sightings of Saloop, or his spirit, in the morgue or in the hospital parking lot. Obviously, Saloop represents the spectre of death. He was everywhere. As Siri and his wife Daeng walked to Si Saket temple, "the dog's yellow eyes had glared from every alleyway and nook. Death was closing in on Dr. Siri [...]" (Cotterill, 2009, p. 105).

The spirit of Saloop reminded Siri of the violence against the dog, committed by one of his begrudging neighbours, which is comparable to violence committed against all the human victims since the gaze of the animal incites the human, taking him across the species boundary, over "the abyssal limit of the human: the inhuman or the ahuman [...] what they call "animal" could look at them, and address them from down there, from a wholly other origin" (Derrida, 2008, pp. 12-13; original emphasis). The animal gaze confirms its agency. It is not only an object to be looked at but can also look back at the human. In addition to a glance/a gaze that the face of the animal initiates, it can provoke speech. Men can address animals and animals, in turn, can "speak" to men. As the human face says "I am," the animal face looks as if to say "Help, I am suffering," with the implication, "like you" (Derrida, 2008, p. 108).

Looking at the face of an animal, a human can be spoken to, implying that an animal is not a machine. It is aware of its own being and can suffer like a human. In Don't Eat Me (Cotterill, 2018), for instance, Geung visits the cargo bay at Wattay airport after the body of a woman is found near Anusawari. Apparently, she was attacked by a pack of starving civets. He later decided to track down a string operation of wildlife trafficking by hitching a ride, with his fiancée Tukta, on a truck carrying crates of wild animals. The spirits of dead civets talked to him and led him to the source of the wild animals. Upon their return, Geung and Tukta related their journey to Siri.

\footnotetext{
"Geung was full of the spirits of the civets. They were calling him. [...] They were on the other side of the runway under gravel," said Tukta.

"Their ssspirits were sad."

"Geung said there were ten of them. We sat with them for a few minutes. I sang them a song." (Cotterill, 2018, p. 124)
} 
Born with Down Syndrome, both Geung and Tukta were gifted with compassion for non-human creatures. They risked their own lives to save wildlife from crimes against animality. Eventually, the gazing and speaking animals, dead and alive, encountered by Siri and Geung under preternatural circumstances, establish animals as "actants" or acting agents (Latour, 2004, p. 75), collapsing the line between subjects and objects. Saloop, the civets, or their spirits, reveal that they are capable of demanding justice and/or humane treatment from their human counterparts. In fact,

\begin{abstract}
[O]bjects and subjects can never associate with one another, humans and non-humans can. As soon as we stop taking non-humans as objects, as soon as we allow them to enter the collective in the form of new entities with uncertain boundaries, entities that hesitate, quake, and induce perplexity, it is not hard to see that we can grant them the designation of actors. And if we take the term "association*" literally, there is no reason, either, not to grant them the designation of social actors. (Latour, 2004, p. 76; asterisk and emphasis in the original)
\end{abstract}

FANTASTIC ANIMALS: NON-HUMAN CREATURES IN PHYSICAL AND SPIRITUAL FORMS

Apart from the speaking and gazing animals that cross the boundary between subjects and objects, there are also fantastic animals in the series. With the use of supernaturalism, they, as active participants, cross the boundary between physical and spiritual forms of non-human animals. The winged horse in Curse of the Pogo Stick (Cotterill, 2008) is one such example. In the novel, Siri, along with Judge Haeng, was abducted to a Hmong village on their way from the city of Phonsavan in Xiang Khouang to Luang Prabang. Upon his arrival, he was greeted as the shaman Yeh Ming, and told that a fourteen-year-old Hmong girl named Chanmee Mua was believed to be possessed by a demon. In order to negotiate her soul back, he needed to perform a ritual that would take him into a trance and see him transition to the other world. Before the séance, a "horse" was prepared. The steed that would carry the shaman to the Otherworld "resembled nothing more than a wonky wooden bench with splinters" (Cotterill, 2008, p. 139). Yet, in the trance, he found himself riding a winged horse between his thighs, the smell and taste of the night air rushing against his face:

\footnotetext{
The muscles of his steed flexed and relaxed as the huge wings found currents of air on which to glide down toward the building tops. Siri's stomach heaved as the creature soared and dove between the skyscrapers. He clung to the cusp of a wing and its force vibrated through him. [...] The winged steed skidded to a stop on the icy sidewalk and white steam smudged the air around her nostrils. Her front hoof scraped the ground and she shook her mane. Siri stayed put. (Cotterill, 2008, pp. 144-145)
}

The shamanic séance landed him on a deserted main street at the mouth of a dark alleyway. The ride was considered an ecstatic journey accompanied by drumming at the beginning. The drum, called the "shaman's horse," is indispensable since drumming constitutes the preliminaries for the ecstatic journey, enabling him to fly through the air to the "Center of the World" (Eliade, 1989, pp. 168; 173). All these beliefs and symbols in relation to the flight of shamans are "figurative expressions for ecstasy, that is, for mystical journeys undertaken by superhuman means and in regions inaccessible to mankind" (Eliade, 1989, p. 174).

The winged horse is one among the fantastic creatures that feature prominently in the detective's experiences of supernatural incidents and contributes to the success of his investigative missions. While the solution of crimes on the mundane level leads to justice, the solution of mysteries on the spiritual plane leads to closure for those involved. Eventually, Chanmee's family learned that she went to the Land of the Dead after giving birth to her twin boys. Hence, one can see that the fantastic animals in the crime series blur the species boundary by taking a human across the border between physical and spiritual dimensions. 


\section{REAL AND SYMBOLIC ANIMALS: BETWEEN ANIMALS AND COLONISED SUBJECTS}

Apart from the fantastic animals, real and symbolic animals in the crime series also contribute to the collapse of the boundary between animals and colonised subjects, between the real and representational, between fiction and reality. In "Animals as Signifiers: Re-Reading Michel Foucault's The Order of Things as a Genealogical Working Tool for Historical Human-Animal Studies," Roscher (2017) proposes the comparability of animals and the generic other, resorting to the term "creaturely" in the discursive as well as physical senses. She suggests that animals are physical living creatures that interact with other animals in their environments. And yet, they have been used as cultural representations, serving as signifiers throughout human history. From postcolonial perspectives, the animal functions as the generic other, "an inferior being that appears lacking and deficient vis-à-vis human" (Roscher, 2017, p. 190). The animal as the other "is thus seen as being constitutive of the notions of the human, humanity, and humanness. Normative concepts of social order are negotiated and conveyed through the discursive figure of the animal as well as the forms of 'othering' it underwrites" (Roscher, 2017, p. 190).

While the othering of animals takes place when they are treated as creatures belonging to another non-human species, the othering of the colonised subject is reified when they are racialised and dehumanised. In The Wretched of the Earth, Fanon (b. 1963) depicts the colonial system as the compartmentalised world, inhabited by two different species - the coloniser, or the ruling species coming from elsewhere, and the colonised, the indigenous population, or "the others." Thus, decolonisation is "quite simply the substitution of one "species" of mankind by another" (Fanon, 2004, p. 1). It is the coloniser who "fabricated and continues to fabricate the colonized subject[s]" (Fanon, 2004, p. 2; original emphasis), dehumanising them and reducing them to the state of animals. When the coloniser speaks of the colonised, he uses zoological terms (Fanon, 2004, p. 7). Therefore, one cannot draw a clear line between the real and the representational, the physical and the symbolic, of the animal. Both are intertwined in the human discourse.

To illustrate the point, in Six and a Half Deadly Sins (Cotterill, 2015), after drinking the magic potion given to her as a cure for her arthritis by Auntie Duang, aka Auntie Voodoo, the shamanic weaver in Muang Xai, Daeng began to feel its side effects. A small tail started to grow on her. Later in I Shot the Buddha, at a Communist Party seminar, she realised that "[s]he had not yet mastered the art of wagging. It was true that no third party had witnessed these supernatural phenomena [...] But there was no denying the clunky wooden chair was playing havoc with Madam Daeng's backside" (Cotterill, 2016 p. 5). Afterwards, Siri found out that Daeng's tail would make her a perfect monkey when the malevolent spirit called phibob possessed her and the villagers of Sawan, in Ubon Ratchathani, without the protection of amulets or house spirits. They started "to growl and salivate, a sure sign the malevolent spirits were recruiting in numbers. [...] As the possessions took hold, more and more swordsmen and monkeys joined the expanding phibob army around the tower [...]" (Cotterill, 2016, pp. 243244). Siri then remarked that, "She made a good monkey. She already had the tail for it" (Cotterill, 2016, p. 246).

The transformation of Daeng and those villagers emphasises the fact that they were not born animals by means of hereditary reproduction but, instead, became animals by means of contagion. Unlike what is postulated in natural history, a becoming-animal always involves a pack, a band, a population, a peopling, in short, a multiplicity (Deleuze \& Guattari, 2007, p. 239). Like a pack of rats or other kinds of vermin, Daeng and the possessed villagers were not hereditarily reproduced. They proliferated by means of contagion, or, in this case, demonic possession. They were becoming-animals, turned into monkeys in both literal and figurative senses. 
Figuratively speaking, Daeng and the residents of Sawan were turned into "monkeys," a species different from that of the colonists. One incident that can illustrate this transformation is in The Second Biggest Nothing (Cotterill, 2019). To celebrate five years of the Communist regime, a large number of foreign journalists, along with Siri, Daeng, Civilai, and Phosy, Chief of the Police Force, were invited to a reception, "to observe the results of all those things that hadn't happened" (Cotterill, 2019, p. 7). They all stayed at the Anou hotel. As Phosy was talking to the Western journalists, one of them, named Bjorn, said:

\footnotetext{
You're all cool about your history as colonized monkeys, but I don't see any French or American newspaper people invited here. You were kind enough to let the Americans keep their consulate open after you took over, but they're down to a diplomatic staff of six, and they aren't allowed to do anything. You nullify your critics with your smiles and your fake indolence. (Cotterill, 2019, p. 72)
}

The same term is earlier used in The Woman Who Wouldn't Die when the Vietnamese engineers called Siri "monkey Lao" on his visit to Pak Lao, Sanyaburi (Cotterill, 2013, p. 186). Historically speaking, the French colonial administration claimed Laos as a tributary of Vietnam in the $1880 \mathrm{~s}$, valuing it "primarily as a resource-rich hinterland for Vietnamese settlement and French exploitation [...] to produce revenue enough to cover administrative costs" (Stuart-Fox, 1997, p. 20). Noteworthily, the stereotypical dichotomy between the Laotian and the Vietnamese in the late nineteenth century was placed between "the dynamic and industrious Vietnamese as opposed to the decadent and lazy Lao" (Ivarsson, 2008, p. 104).

\section{DE-CENTRING THE ANTHROPOCENTRIC DEFINITION OF CRIME}

Initially, the speaking and fantastic animals in the Siri Paiboun series serve to collapse the boundary between subjects and objects, and the physical and spiritual. Next, the interconnectedness between real and symbolic animals contributes to the border crossing of human and non-human animals, and the dismantled distinction between animals and colonised subjects. Yet, the trans-species traffic also brings about the inevitable corollary, the de-centring of the anthropomorphic definition of crime. Once, the definition of "crime" had been based solely on the adoption of laws aimed at regulating human conduct in relation to the state (Black, 1979, p. 334). Later, additional laws were adopted aiming at regulating the human treatment of animals in Britain. They include The Act to Prevent the Cruel and Improper Treatment of Cattle of 1822; The Cruelty to Animals Act of 1835, repealed and replaced in 1849, 1850, 1854, and 1876; The Wild Animals in Captivity Act of 1900; The Protection of Animals Act of 1911, amended in 1921, 1934, and 1954; The Animal Welfare Act of 2006 (Robles, 2016, pp. 10-11).

As wildlife trafficking is now considered a crime, a poignant question is asked in Don't Eat Me (Cotterill, 2018). How can one differentiate wild animals from domestic animals? Smuggled wildlife ends up in zoos across the globe. When humans visit zoos and look at those animals living in confinement, we become aware that it is not a viable solution to interspecies encounters. Berger (1992) argues in "Why Look at Animals?" that the zoos as we know them were first founded in the late-eighteenth to the early-nineteenth centuries - the London Zoo in 1828, the Jardin des Plantes in 1793, and the Berlin Zoo in 1844. They brought considerable prestige to the national capitals, accruing to the private royal menageries. Afterwards, the nineteenth-century public zoos were an endorsement of modern colonial power. The capturing of the animals was a symbolic representation of the conquest of all distant and exotic lands. The claim was that: 
[I]t was another kind of museum, whose purpose was to further knowledge and public enlightenment. And so the first questions asked of zoos belonged to natural history; it was then thought possible to study the natural life of animals even in such unnatural conditions. (Berger, 1992, p. 21)

Nonetheless, as one proceeds from cage to cage, "not unlike visitors in an art gallery who stop in front of one painting, and then move on to the next or the one after next," they are looking at "something that has been rendered absolutely marginal" (Berger, 1992, pp. 23-24). A similarly marginalised creature is found in Thirty-Three Teeth (Cotterill, 2005). A malnourished and maltreated Malay black bear mysteriously slipped out of its confinement in the compound of the Lan Xang hotel, and was reportedly seen by the Monument of the Unknown Soldier, located near That Luang. The bear might have been responsible for three deaths of women supposedly attacked by a wild animal. Finally, it was discovered that the bear had earlier been smuggled from the hotel to the Russian circus troop in Silver City, a walledoff compound two minutes' walk from the monument, reputedly a Southeast Asian base for the KGB (Cotterill, 2005, p. 114). Somehow, she escaped from the truck during the rescue, and came to visit Siri in the midst of the night. Sleeping in a mosquito net on the veranda,

\footnotetext{
Siri turned his head and looked into the darkness, and into the dull eyes of a bear. It was so close, its breath moved the net. It was close enough that Siri could see fresh blood at the corner of its mouth; close enough for him to smell the decay on its teeth.

It was sitting, watching the doctor. He felt its power over him. But Siri wasn't fearful. Yes, he believed this was unreal in some way, but he also had an instinct that the animal wasn't there to hurt him. The creature, its inspection over, rose painfully, turned, and walked off into the mobile jungle. (Cotterill, 2005, pp. 3435)
}

This painful encounter reminded Siri of the impossibility of the non-hierarchised relationship between the human and the animal in a zoo setting. The bear believed she was going to be slaughtered, and decided to seek help from Yeh Ming, the spirit of the Hmong shaman he was hosting. Her wish was finally reciprocated. She was eventually transferred to the Soviet clinic where her maladies were treated and was later returned to Silver City to spend the final months in relatively blissful freedom.

The plight of the black bear seems to resonate with that of the wildlife Geung saved. In the end of Don't Eat Me, he gave a speech to the guests at his wedding party. He called himself an animal, while referring to Ugly as an animal "called a dog."

\footnotetext{
"I am Geung Wattajak and I am an animal. [...] And all of you are animals."

"This is Ugly," said Geung. "He's a different animal. He's an animal called a dog. People call him a dumb animal because he can't speak and because he licks his arse." (Cotterill, 2018, p. 286)
}

Once dehumanised by being called a dumb animal, Geung hopes his speech highlights the need for humans to stop thinking they are better than other animals. All creatures, for him, contribute something to the planet (Cotterill, 2018, p. 287). In hindsight, Geung's wedding speech, and the racialisation of colonial subjects, echo the perpetual attempt to patrol the hiatus between non-humans and humans. In The Open: Man and Animal, Giorgio Agamben (2004) explores the interspecies caesura, calling it the "zone of exception." The concept of "life" in Western culture, to him, "cannot be defined, yet, precisely for this reason, must be ceaselessly articulated and divided" (Agamben, 2004, p. 13; original emphasis). The term Homo in the binomial Homo sapiens, coined in 1758 by Carl Linnaeus (1707-1778), Swedish botanist and zoologist, is actually a device for producing the recognition of the human. Homo, meaning "resembling man," is "the anthropological machine of humanism," an apparatus that builds a holding suspended between the animal and the human (Agamben, 2004, p. 29). This machine functions by means of an exclusion and an inclusion, precisely because, 
[T] he human is already presupposed every time, the machine actually produces a kind of state of exception, a zone of indeterminacy in which the outside is nothing but the exclusion of an inside and the inside is in turn only the inclusion of an outside. (Agamben, 2004, p. 37)

Reading along these lines, Geung's speech, after he heard the spirits of the dead civets and the pig whose life he had saved, underlines the absence of the caesura between the human and the animal. It demonstrates that animals in the crime series are not regarded as tools or companions to humans, but active participants that can address humans with their speech or gaze, in both physical and spiritual forms, in real and symbolic representations. Under supernatural circumstances, animals in this crime series function as a constant reminder of the need to de-centre the anthropocentric definition of crime since they can suffer like humans, and violence against them should be placed on the same level as violence against humans.

\section{CONCLUSION}

The article starts by posing a question regarding the nature and roles of animals and supernaturalism in the Siri Paiboun crime series, comprised of fourteen novels by the British writer Colin Cotterill. In those novels, several non-human characters are often featured under preternatural circumstances, such as in trances, possessions, and dreams, offering a viable critical intervention of crime fiction studies.

The article then provides a brief survey of animal studies in social and historical contexts before being introduced to literary studies. Critical animal studies emerged in the late twentieth century, contemplating the meanings of animals defined in diverse social and historical milieus. In the early twenty-first century, the field of study expanded to include literary studies. From then on, the study of animals in literature has been developed into three major tracks: the modernist approach that takes into account the still-intact species boundary; the postmodernist/postcolonialist approach that challenges the species boundary; the attempt to redefine human-animal relations. Afterwards, the article progresses on to the roles of animals in one particular literary genre, namely, crime fiction. Their roles are categorised into three major groups: animals that function as tools used to commit crimes; animals that serve as companions to humans; animals that demonstrate their own agency undetermined by humans.

Eventually, the article proceeds to its main focus, i.e. the interconnectedness between animals and supernaturalism in Cotterill's crime series. Nevertheless, animals in the series are not just tools or companions to humans, but agents inhabiting liminal space and time. Animals encountered by Siri and Geung, the coroner and his morgue assistant, are classified according to their modes of representation: speaking and gazing animals that cross the boundary between subjects and objects, and between the physical and spiritual - the dog named Saloop, and smuggled civets; fantastic animals that cross the border between physical and spiritual forms the winged horse in a shamanic séance; real and symbolic animals that collapse the boundary between animals and colonised subjects - Daeng and her fellow "monkey Lao." Nevertheless, the trans-species traffic also brings about the inevitable corollary, the de-centring of the anthropomorphic definition of crime. This demonstrates that animals in the Siri Paiboun series are not merely regarded as tools or companions to humans, but active agents that can actually suffer like humans. Therefore, crimes against animals should be handled in the same way as crimes against humans.

\section{ACKNOWLEDGEMENTS}

The publication of this article was supported by the Research Fund of the Department of Western Languages, Faculty of Archaeology, Silpakorn University. 


\section{REFERENCES}

Agamben, G. (2004). The open: Man and animal (K. Attell, Trans.). Stanford: Stanford University Press.

Arluke, A. \& Sanders, C. R. (1996). Regarding animals. Philadelphia: Temple University Press.

Armstrong, P. (2008). What animals mean in the fiction of modernity. New York: Routledge.

Berger, J. (1992). About looking. New York: Vintage Books.

Black, H. C. (1979). Black's Law dictionary. St. Paul: West Publishing.

Burdett, J. P. (2003). Bangkok 8. London: Corgi Books.

Burt, J. (2004). Animals in film. London: Reaktion Books.

Calarco, M. (2008). Zoographies: The question of the animal from Heidegger to Derrida. New York: Columbia University Press.

Carstens, D. (2017). Tricksters, animals, new materialities, and indigenous wisdom. In Woodward, W. \& McHugh, S. (Eds.). Indigenous creatures, native knowledges, and the arts: Animal studies in modern worlds. (pp. 93-115). London: Palgrave Macmillan.

Cohen, E. (2003). Animals in medieval perceptions: The image of the ubiquitous other. In Manning, A. \& Serpell,

J. (Eds.). Animals and human society: Changing perspectives. (pp. 59-80). London: Routledge.

Cole, L. (2011). Human-animal studies and the eighteenth century. The Eighteenth Century. 52(1), 1-10.

Cole, L. (2019). Imperfect creatures: Vermin, literature, and the sciences of life, 1600-1740. Ann Arbor: University of Michigan Press.

Cotterill, C. (2004). The coroner's lunch. New York: Soho Press.

Cotterill, C. (2005). Thirty-three teeth. New York: Soho Press.

Cotterill, C. (2007). Anarchy and old dogs. New York: Soho Press.

Cotterill, C. (2008). Curse of the pogo stick. New York: Soho Press.

Cotterill, C. (2009). The merry misogynist. New York: Soho Press.

Cotterill, C. (2013). The woman who wouldn't die. New York: Soho Press.

Cotterill, C. (2015). Six and a half deadly sins. New York: Soho Press.

Cotterill, C. (2016). I shot the Buddha. New York: Soho Press.

Cotterill, C. (2018). Don't eat me. New York: Soho Press.

Cotterill, C. (2019). The second biggest nothing. New York: Soho Press.

Deleuze, G. \& Guattari, F. (2007). A thousand plateaus: Capitalism and schizophrenia (B. Massumi, Trans.). Minneapolis: University of Minnesota Press.

Derrida, J. (1978). Writing and difference (A. Bass, Trans.). Chicago: The University of Chicago Press.

Derrida, J. (2008). The animal that therefore I am (D. Wills, Trans.). New York: Fordham University Press.

Descartes, R. (2006). A discourse on the method of correctly conducting one's reason and seeking truth in the sciences (I. Maclean, Trans.). New York: Oxford University Press.

Doyle, A. C. (1994). The hound of the Baskervilles. New York: Quality Paperback Book Club.

Eliade, M. (1989). Shamanism: Archaic techniques of ecstasy (W. R. Trask, Trans.). London: Arkana Penguin Books.

Fanon, F. (2004). The wretched of the earth (R. Wilcox, Trans.). New York: Grove Press.

Franklin, A. (1999). Animals and modern cultures: A sociology of human-animal relations in modernity. London: SAGE Publications.

Heidegger, M. (1995). The fundamental concepts of metaphysics: World, finitude, solitude (W. McNeill \& N. Walker, Trans.). Bloomington, IN: Indiana University Press.

Herman, D. (2016). Literature beyond the human. In Herman, D. (Ed.). Creatural fictions: Human-animal relationships in twentieth-and twenty-first-century literature. (pp. 1-15). London: Palgrave Macmillan.

Huggan, G. \& Tiffin, H. (2010). Postcolonial ecocriticism: Literature, animals, environment. London: Routledge.

Ivarsson, S. (2008). Creating Laos: The making of a Lao space between Indochina and Siam, 1860-1945. Copenhagen: Nordic Institute of Asian Studies Press.

Kalof, L. (2007). Looking at animals in human history. London: Reaktion Books.

Latour, B. (2004). Politics of nature: How to bring the sciences into democracy (C. Porter, Trans.). Cambridge: Harvard University Press.

Lundblad, M. (2009). From animal to animality studies. PMLA. 124(2), 496-502.

McHugh, S. (2009). Literary animal agents. PMLA. 124(2), 487-495.

Ohrem, D. \& Calarco, M. (Eds.). (2018). Exploring animal encounters: Philosophical, cultural, and historical perspectives. London: Palgrave Macmillan.

Payne, D. G. (2017). Border crossings: Animals, tricksters and shape-shifters in modern Native American fiction. In Woodward, W. \& McHugh, S. (Eds.). Indigenous creatures, native knowledges, and the arts: Animal studies in modern worlds. (pp. 185-204). London: Palgrave Macmillan.

Philo, C. \& Wilbert, C. (2000). Animal spaces, beastly places: New geographies of human-animal relations. London: Routledge. 
Poe, E. A. (2008). The murders in the rue morgue. In Widger, D. \& Traverso, C. (Eds.). The works of Edgar Allan Poe, Volume 1. The Project Gutenberg. Retrieved April 16, 2021 from https://www.gutenberg.org/files/2147/2147-h/2147-h.htm\#chap07

Robles, M. O. (2016). Literature and animal studies. London: Routledge.

Rohman, C. (2009). Stalking the subject: Modernism and the animal. New York: Columbia University Press.

Roscher, M. (2017). Animals as signifiers: Re-reading Michel Foucault's The order of things as a genealogical working tool for historical human-animal studies. In Ohrem, D. \& Bartosch, R. (Eds.). Beyond the humananimal divide: Creaturely lives in literature and culture. (pp. 189-214). London: Palgrave Macmillan.

Simenon, G. (2013). The yellow dog (L. Asher, Trans.). London: Penguin Books.

Stuart-Fox, M. (1997). A history of Laos. Melbourne: Cambridge University Press.

Woodward, W. (2017). 'The only facts are supernatural ones': Dreaming animals and trauma in some contemporary southern African texts. In Woodward, W. \& McHugh, S. (Eds.). Indigenous creatures, native knowledges, and the arts: Animal studies in modern worlds. (pp. 231-248). London: Palgrave Macmillan. 